\title{
LIBERIA:
}

\section{Civil War and the Complications SALWs Proliferation}

\author{
Al Chukwuma OKOLI \\ George A. ATELHE \\ Ted A. ALPHONSUS
}

\begin{abstract}
This paper examines the complications of SALWs in the context of armed conflict with particular reference to the Liberian civil war. Using an exploratory analysis that relied on documentary data, as complemented by insights from Key Informant Interview (KII), the paper observed that the incidence of SALWs proliferation was one of the factors that complicated the Liberian crisis. The paper posits that the complications of SALWs proliferation in Liberia during and after the National crisis (1989-2003) posed a threat to the country's national security. The threat is evident in the collateral impact of armed violence that characterized the Liberian

\section{Al Chukwuma OKOLI}

Senior Lecturer, Department of Political Science

Federal University Lafia, Nigeria

E-mail: okochu007@yahoo.com

\section{George A. ATELHE} crisis as well as the wave of armed criminality that has punctuated the country's history in the aftermath of the crisis. In the light of its dire effects vis-à-vis sustainable peace, security and stability, this paper submit that SALWs proliferation has posed a threat to Liberian national security both in the conflict and post-conflict eras.
\end{abstract}

Senior Lecturer, Department of Political Science

University of Calabar, Nigeria

E-mail: atelheson@yahoo.com

Ted A. ALPHONSUS

MPhil Candidate, Department of Political Science

(International Relations Programme)

Ahmadu Bello University, Zaria, Nigeria.

E-mail: ebony_ted@yahoo.com

Conflict Studies Quarterly

Issue 29, October 2019, pp. 43-61

DOI:10.24193/csq.29.4

Published First Online: 04/10/2019

Keywords: Liberia, Liberia crisis, SALWs, SALWs proliferation, national security, violent crime.

\section{Introduction}

One of the critical drivers of the proliferation of Small Arms and Light Weapons (SALWs) globally is armed conflict. In the aftermath of violent conflicts, large number of arms, largely SALWs, often remains in the hands of government forces, warring parties, and civilians. The illicit spread of these 
arms contributes to an atmosphere of insecurity which further heightens the quest for arms acquisition. Ex-combatants and criminals have often leveraged on arms at their disposal to perpetrate violent crime in post-conflict situations. The consequence is a cycle of violence which challenges post-conflict peacebuilding and development (Gyong \& Ogbadoyi, 2013).

Of all the million tons of SALWs in circulation in the world today, nearly a half is illegally held by civilians. Although the distribution of these weapons is largely uneven geographically, demographically, and institutionally, the bulk of the arms have ended up in the hands of dangerous non-state groups which are inclined to nefarious agendas. These arms are therefore used to fuel, intensify and exacerbate conflicts and instability. While conflicts subsist, there prevails a continuous need for more arms and ammunition; hence a vicious cycle of violence is perpetuated (Onuoha, 2006).

Generally, arms proliferation and misuse negates post-conflict reconstruction and development, obstructs the delivery and distribution of humanitarian and developmental aid, and holds the potential to destabilize neighboring states and societies. In view of its destabilizing implications of SALWs, its mitigation has been a prime priority in the contemporary global peace-building agenda. Thus, the removal of weapons from circulation in post-conflict situations, usually through disarmament, demobilization and reintegration (DDR) Programmes, has been an integral component of the stabilization policies in post-conflict states and regions.

Globally, the phenomenon of SALWs proliferation has posed serious, humanitarian and developmental threats to the comity of nations. The post-Cold War arms liberalism accelerated pace of globalization, as well as the rise of asymmetric violence in many parts of the world, has promoted the circulation of both legal and illegal across the ever compromised international borderlines and frontiers. Similarly, the upsurge in intra-state conflicts has created a staggering demand for the SALWs, thereby making them weapons of choice in conventional and unconventional armed violence (Onuoha, 2006). But while all nations are variedly exposed to the threat of SALWs proliferation; states in post-conflict situations are more deeply enmeshed in its lethal complications. It is in the light of this fact that this paper seeks to examine the collateral effects and complications of SALWs proliferation in post-conflict situations in Africa with particular reference to Liberia.

\section{Historicizing the Liberian Conflict}

The Liberian conflict occurred in two phases: 1989-1997 and 1997-2003. To better understand the causes of the conflict in Liberia, a brief background of the country's civil war is required. The Liberian civil war started in 1989. The country was ruled by Americo-Liberians (American descendants) until 1980 when Sergeant Samuel Doe, a native Liberian, became the first president of Liberia (Gariba, 2011). This development 
was welcomed with excitement by the average Liberians, who for the first time, thought they were going to be liberated under Samuel Doe's regime.

However, Doe's regime became very authoritarian, discriminatory and abusive of human rights in Liberia. It was as a result of the repressive regime of Samuel Doe that Charles Taylor began an attack in 1989 which finally led to the overthrow of Samuel Doe's government by a break-away faction from the rebels' group of Charles Taylor (Gariba, 2011). This group, known as the Independent National Patriotic Front of Liberia (INPFL), was led by Prince Johnson in September 1990. The ECOWAS Monitoring Group (ECOMOG), a regional peacekeeping group of the Economic Community of West African States (ECOWAS), mediated, and Dr. Sawyer acted as interim president until the 1997 elections when Charles Taylor of the National Patriotic Front of Liberia (NPFL) was elected as president (Fawole, 2001).

Two years later, the Liberian civil war began in earnest with two principal rebel groups, namely Movement for Democracy in Liberia (MODEL) and Liberians United for Reconciliation and Democracy (LURD). The former emerged from the border between Ivory Coast and Liberia while the latter was started by a group of exiled Liberians in Guinea. These rebel groups confronted Taylor's government from different fronts leading to the destabilization of the country. With international pressures and ECOWAS intervention, Charles Taylor was forced to resign in 2003. He went into exile in Nigeria and his vice-president, Gyude Bryant, was chosen to act as interim president until the 2005 election, when Ellen Johnson Sirleaf was elected and sworn in as the President of Liberia in January 2006 (Gariba, 2011).

In the extant academic literature, many reasons have been given for the outbreak of the Liberian conflict. According to Adebajo (2002, p. 19), the conflict is generally attributed to a crisis of governance. Adebajo outlines six key issues, as indices of bad governance, that contributed to the Liberian War: 'the exclusionary rule of the Americo-Liberian Oligarchy, the brutal and inept rule of Samuel Doe; the deleterious effects that Doe's rule had on the armed forces of Liberia, ethnic rivalries and personal ambitions that resulted from Doe's rise to bloody power; and the destabilizing effects of the withdrawal of the U.S. support from Doe, a strategic Cold War ally' (Adebajo 2002, p. 19).

In the light of foregoing, it can be seen that Liberians suffered from the Americo-Liberian rule in that they were systematically discriminated against in terms of employment, political representation and development projects. But this situation did not change with the advent of Samuel Doe, a native Liberian, on the saddle of power in 1980. In effect, Samuel Doe's government became more repressive, authoritative and abusive of human rights. Indeed, there were political, social and economic factors that led to a resumption of the civil war in 1989 (Adebanjo, 2002). In the first place, after the 1985 elections, instead of establishing inclusive democratic governance, Doe deepened ethnic 
exclusion by disproportionately appointing his own tribe, the Krahns, and co-opted the Mandingoes, who were the wealthiest businesspeople, into his cabinet to the neglect of the rest of the fourteen tribes of Liberia. Secondly, the extra-judicial execution of Colonel Thomas Quinwokpa and his military men, including the Gios and Manos, brought about counter-reaction. Thirdly, the execution of William Tolbert and several members of his cabinet and the reckless confiscation of property led the Americo-Liberians to support Charles Talyor's uprising (Gariba, 2011).

In light of the foregoing, it is evident that the principal cause of the civil war in Liberia is the issue of crisis of governance. This was variously exhibited in the abuse of human rights, dictatorial rule, social and ethnic exclusion, and institutional failures led to the overthrow of Doe's government and the turmoil that then engulfed the country. Samuel Doe's regime was very repressive and pursued ethnic discrimination policies. As Amos Sawyer argues, 'Sergeant Samuel Doe ascended to power from the lumpen elements of the Liberian Army. Within a few years, he purged the military of all his rivals and of its trained officers and relied on an under-disciplined core recruited largely by his Krahn ethnic groups' (Sawyer, 2004, p. 444). The implication of this is that the professionalism of the military was undermined, and this not only negated merit principles in the military but also weakened the military institution.

\section{Nature, Incidence and Causes of SALWs proliferation in Liberia}

The main objective of the study is to examine the nature, incidence and causes of SALWs proliferation in Liberia. The outcome of the study's interviews revealed that Liberia represents a typical instance of the countries of sub-Saharan where SALWs proliferation constitutes a veritable national security challenge. This fact has been corroborated by secondary sources to the effect that the country has variously served as the point origin, transit and destination of illicit arms/weapons circulated through arms trafficking. In effect, the country stands out as a typical volatile zone in terms of arms trafficking and SALWs proliferation in the Mano River Region (Fawole, 2001; Alemika, 2014).

The reasons for the negative Liberian profile in respect of SALWs proliferation were variously identified by the study's key informants as:

1. The corrupt and authoritarian regime of Samuel Doe that fertilized the seed of civil discord and dissent in the country;

2. The incident of the Liberian civil wars and the waves of civil conflicts that characterized its aftermath;

3. The proliferation of rebel/militia groups in the wake of the escalation of the Liberian crisis;

4. The meddling of neighboring states in the Liberian internal security situation;

5. Illegal mining and trading of diamond that provides funding for arms merchandizing; 
Table 1: Fourteen Years Of Conflict In Liberia: A Timeline of Key Events

Sn Timeline Event

1. December 1989

Charles Taylor leads his National Patriotic Front of Liberia (NPFL) in an invasion of Northern Liberia-the first step of a plan to topple President Samuel Doe

The Economic Community of West African States (ECOWAS) sends an intervention

2. 1990 force to Liberia: the monitoring group (ECOMOG). Doe is executed by a breakaway faction of the NPFL, led by Prince Johnson

3. March 1991

Liberian refugees of the Revolutionary United Front (RUF) invade Sierra Leone from Liberia, led by Foday Sankoh, an associate of Charles Taylor

Liberian refugees from Guinea and Sierra Leone, who had backed ex-President Doe,

4. May 1991 form the United Liberian Movement for Democracy in Liberia (ULIMO) a rival to Taylor's NPFL

5. September 1993

The UN security council establishes the United Nations Observer Mission in Liberia (UNOMIL)

6. August 1995

A peace agreement is signed in Abuja, calling for a cease-fire and disarmament of fighting forces.

Fighting erupts between ULIMO-J and the NPFL and spreads to Monrovia.

7. 1996 ECOMOG troops regain control and another ceasefire is declared.

ECOMOG launches a disarmament and demobilization programme.

The RUF, backed by Taylor topples President Kabbah in Sierra Leone.

8. May 1997 Sierra Leone's Kamajor fighters, who supported ex-president Kabbah, flee to Liberia where they unite with ULIMO rebels

9. July 1997

Charles Taylor is elected president. His National Patriotic Party wins a majority of seats in the National Assembly

10. September 1997 UNIOMIL withdraw

11. February 2000 Anti-Taylor groups including the Kamajors and ULIMO, unite to form Liberians United for Reconciliation and Democracy (LURD)

12. July $2000 \quad$ LURD invades northern Liberia from Guinea

13. September 2000 Taylor counter-attacks LURD by sending RUF forces into Guinea

14. May 2001

The UN Security Council imposes an arms embargo and sanctions on Liberia for its continued support of the RUF

15. February 2002 LURD advances to within $50 \mathrm{~km}$ of Monrovia. Taylor declares a state of emergency

16. March 2003 MODEL (movement for Democracy in Liberia) emerg

17. June 2003 The special Court of Sierra Leone issues a indictment for war crimes against Charles Taylor due to his alleged support for the RUF

ECOWAS peacekeepers arrive in Liberia. A CPA is signed in Accra

18. August 2003 Taylor accepts an offer to asylum in Nigeria and an interim government is establishment, headed by Gyude Bryant.

19. September 2003 The UN security council establishes the United Nations Mission in Liberia (UNMIL)

20. December 2003 Liberia's DDRR programme is launched.

Source: Small Arms Survey (2005, p. 111). 
6. The failure of the Liberian state and successive governments to enforce public security, law and order in the face of the raging civil unrest, armed conflicts and governance interregnum;

7. The activities of local weapon crafters and arms traffickers that perpetuate the underground armed business in the country;

8. The activities of transitional syndicates that specialize on arms dealing and trafficking in both Liberia and the Mono River axis

Studies carried out by Fawole (2001) Alemika (2014) as well as that of Stohl and Hogendoorn (2010) largely affirmed the aforementioned observations. As observed by Fawole (2001), the advent and subsequent escalation of the Liberian crisis complicated the arms of proliferation debacle in the country. In this context, small and light arms became veritable instruments of armed struggles that characterized the civil ambiance of the country from late 1980 s to early 2000 s. This scenario was further compounded by the rise of a multiplicity of armed militia and militant/rebel groups in the country in the course of the civil conflicts.

The relative structural and functional failure of the Liberian state in the wake of the Liberian crisis led to the politicization and bastardization of the national armed forces. Most of the study's key informants opined that this trend helped in accentuating the SALWs proliferation debacle in the country. According to them, what resulted in this process was the emergence of a highly undisciplined, disloyal, partisan, and sectionalized national armed forces that was devoid of professional etiquette and discipline (personal communication, June 2015). In effect, the military became engrossed in the civil unrest that prevailed in the country, which worsened the SALWs proliferation syndrome.

The outcome of the Liberian civil conflict was widely implicated by the research informants. Military personnel interfaced within the course of the research at the National Defence College, Abuja maintained that in the aftermath of the Liberian crisis, huge stockpiles of arms/weapons had circulated in the country, with the bulk of them falling into wrong hands (Personal communication, June 2015). Consequently, small and light arms/weapons became a common possession by private individuals and organizations in the country. Worse still, the activities of dissident ex-combatants and criminal syndicates who eke out a living through arms trafficking have made the problem of SALWs proliferation rather endemic and intractable in the country: (cf. Fawole, 2001).

Generally, the drivers of SALWs proliferation in Liberation can be identified thus:

1. The Liberian civil conflicts.

2. Illicit trade on natural resources (rubber timber, and diamond).

3. Arms trafficking by organized and opportunist local and transnational arms cartels.

4. Gunrunning among private individual as well as public security operatives.

5. Plundering of government armories by dissident soldiers.

6. The proliferation of rebel/militia groups. 
7. Poor law enforcement, leading to criminal franchise and impunity.

8. Mass poverty and unemployment.

9. Porous and poorly policed international borders in Liberia.

10. Warlordism and populist militancy, etc. (various personal communication, May June, 2015).

Table 2: United Nations Arms Embargoes on Targets in Sub-Saharan African (2006-2010)

\begin{tabular}{lll}
\hline \multicolumn{1}{c}{ Target } & \multicolumn{1}{c}{ Entry into force } & \multicolumn{1}{c}{ Lifted } \\
\hline Cote d'Ivoire & 15 Nov 2004 & - \\
Congo, DRC (NGF) & 28 July, 2003 & - \\
Eritrea & 23 Dec, 2009 & - \\
Liberia (NGF) & 19 Nov, 1992 & - \\
\hline Rwanda (NGF) & 16 Aug 1995 & 10 July, 2008 \\
Sierra Leone (NGF) & 5 June 1998 & 29 Sept 2010 \\
Somalia (NGF) & 23 Jan, 1992 & - \\
\hline Sudan (Darfur region) & 30 July, 2004 & - \\
\hline
\end{tabular}

Note: NGF (in bold fonts)=Non-Government Forces

Source: Wezeman \& Wezenan (2011:27).

Table 5.1 lists Liberia (in bold Italics) as one of the target countries for arms embargo. Although the embargo was actually on non-governmental forces, the implication is that the issue of SALWs proliferation was a serious concern in Liberia during the period under review.

\section{Forms of Arms/Weapons proliferated in Liberia}

The second objective of the study was to ascertain the forms of Arms/weapon commonly proliferated in Liberia. The outcome of the field-study indicated that they largely fall within the category classified by the United Nations Report of the panel of Governmental Experts on Small Arms (UNGA, 2002) as Small Arms and Light Weapons (SALWs). Table 3 highlights the forms of arms that constitute the afore-stated categories.

Table 3: Light and Small Arms proliferated in Liberia

\begin{tabular}{cl}
\hline \multicolumn{1}{c}{ CATEGORY } & \multicolumn{1}{c}{ FORMS } \\
\hline Small arms & $\begin{array}{l}\text { Revolvers and self-loading pistols, rifles and carbines, sub-machine guns, assault rifles, and } \\
\text { light machine guns }\end{array}$ \\
Light weapons & $\begin{array}{l}\text { Heavy machine guns, hand-held under-barrel and mounted grenade launchers, portable an- } \\
\text { ti-aircraft guns, recoilless rifles, portable launchers of anti-tank missile and rocket systems, } \\
\text { portable launchers of anti-aircraft missile systems, and mortars of calibers of less than 100mm. }\end{array}$ \\
\hline
\end{tabular}

Source: UNGA, 2009. 
Available data suggest that small arms constitute the bulk of arms/weapons proliferated in Liberia. Included in this category are riffles, sub-machine guns and pistols. The disarmament program held in Liberia from April to October 2004 resulted in the recovery of 20,488 rifles and sub-machine guns (Small Arms Survey, 2005). This clearly points to the fact that small arms and widely in circulation in Liberia. This affirms the views of most of the study's informants that SALWS is the most dominant category of arms in proliferation in Liberia (personal communication, May-June 2015).

Box 1: Arms and Weapons used in the Liberian Wars (Small Arms Survey, 2005)

During the Liberia armed conflict, the rebel forces used various forms of small arms including: self-loading pistols, M72 AB2 automatic rifles, FN FAL rifles, AKM and AK-47 assault rifles, M-16 rifles, SKS rifles, PKM light machine guns RPK and RPD machine guns, and Chinese M-60 type $7.622 \mathrm{~mm}$ light machine guns. The Armed Forces of Liberia (AFL) mainly used Chinese-made AK-47s, alongside other progovernment forces.

Both rebel and government forces relied extensively on light weapons, including rocket-propelled grenade launchers (RPGs), RPO-type grenade launchers, Britishmade $60 \mathrm{~mm}$ and $81 \mathrm{~mm}$ mortars and DSHK $12.7 \mathrm{~mm}$ heavy machine guns, as well as SA-7/Strella surface-to-air missiles. The AFL and pro-government forces used universal and general-purpose machine guns and RPGs.

Available secondary sources indicate that since the end of the Liberia crisis in 20032004, the trend of SALWs proliferation in the country has significantly changed. Nowadays, SALWs proliferation in the country is more remarkably skewed in favor of small arms, which are apparently in high demand in the region (Alemika, 2014). Some of the small arms in circulation in the post-conflict Liberia were locally produced while a good number were smuggled into the country through the activities of illicit arms merchants and traffickers (Alemika, 2014). Most of these arms remain in the hands of petty and organized criminal gangs who use them to perpetrate various patterns of armed criminality. A significant proportion of small arms in circulation, however, may be in the hands of private individuals and organizations which use them for self defence and/or protection.

\section{Sources of Proliferated Arms in Liberia}

The outcome of the study chats showed that Liberia variously serves as points of arms origination, arms transits, and arms destination. As a point of arms origination, the country has an underdeveloped, underground arms industry that manufactures different varieties of small arms. This industry is operated by local crafts-persons who use rudimentary techniques and tools to design assorted kinds of small arms and weapons. 
Their products constitute, however, a marginal percentage of the total volume of arms in circulation in Liberia (personal communication, June 2015).

As a point of transition, Liberia presents a veritable route for arms peddling and trafficking within the wider context of the Mano River Region. In this regard, arms smugglers and traffickers, representing various transnational underworld syndicates, often 'push' their arms through the territorial spheres of Liberia to other destinations within and without the Mano River axis. In this process, residues of arms often end up in Liberia. As a destination for SALWs proliferation, Liberia presents a huge market for both legal and illegal arms purchase. In effect, arms supplies from local, continental and international sources find their way into the Liberia flourishing underworld arms market for onward circulation. This constitutes a critical dimension of the SALWs proliferation debacle in the country.

Generally, two sources of arms were principally identified by the research interviewees, namely, Local sources and international sources. The former refers to the arms supplies emanating from the domestic environment of Liberian, usually the product of the rudimentary underworld arms industry operated by local semi-skilled craftsmen. The latter refers to arms transfers, whether legitimate or legitimate, legal or illicit, originating from other countries within Africa or beyond. The foregoing findings from personal communication were corroborated by secondary sources. For instance, the Small Arms Survey (2005) alleged that Burkina Faso and Libya have allegedly served as transshipment points of arms transferred to Liberia. Similarly, Honey Kong and Mainland China allegedly facilitated the transfer of Chinese made weapons to Liberia through the Oriental Timber Company controlled by the ex-president Charles Taylor (Small Arms Survey, 2005, p. 303).

One important driver of SALWs proliferation in Liberia is stealing from the government armories. Some key informants interacted with at the Liberian Foreign Commission in Abuja observed that some soldiers, who defected from government military to rebel forces, carted away from some government arms/weapons. According to a personal communication, in some cases, some of the arms/weapons were sold to private individuals or militia groups. In addition, government armories were massively looted by rebels during the course of the armed conflict in the country. Furthermore, criminal elements in the government military have often stolen from the government armories for sale. The gamut of arms/weapon coming from these sources constitutes part of the SALWs proliferation question in Liberia (personal communication, June 2015).

In terms of international transfers of arms, our personal communications revealed that Liberia relied on importation from a number of industrialized countries such as United States of America, Russia, China, Ukraine, Yugoslavia, Bulgaria, Italy, Spain, Iran, and so on. Some of the transactions were affected through the use of fronts or proxies for strategic reasons (personal communication, June 2015). Yet, some of them were done 
through deliberate tactical subterfuge and deceit as relevant authoritative secondary sources corroborate. For instance, the Liberian government once admitted of acquiring significant quantities of weapons from the former Yugoslavia from June to August 2002 through the Balgrade-based Temex brokering company, using false Nigerian end-user certificates (Small Arms Survey, 2005, p. 330). Information reflected on table 4 showing hereunder is instructive in respect of the aforementioned ex-Yugoslavia arms deal.

Table 4: List of Weapon Shipments from Ex-Yugoslavia to Liberia from June to August 2002, as found in the UN panel of Experts on Liberia Repot (October 2002)

\begin{tabular}{|c|c|c|}
\hline $\begin{array}{l}\text { Date of Flight landing } \\
\text { in Liberia }\end{array}$ & Contents of Flight & $\begin{array}{l}\text { Weight } \\
\text { (Tonnes) }\end{array}$ \\
\hline 1 June 2002 & $\begin{array}{l}1,000 \text { automatic rifles }(7.62 \times 39 \mathrm{~mm}) 498,960 \text { cartridges }(7.62 \times 39 \mathrm{~mm}, \mathrm{M} 67) \\
2,000 \text { hand grenades }(\mathrm{M} 75)\end{array}$ & 21 \\
\hline 7 June, 2002 & $\begin{array}{l}1,000 \text { automatic rifles }(7.62 \times 39 \mathrm{~mm}) 1,260,000 \text { cartridges }(7.62 \times 39 \mathrm{~mm}, \mathrm{M} 67) \\
2,496 \text { hand grenades }(\mathrm{M} 75)\end{array}$ & 40 \\
\hline 29 June 2002 & 1,500 automatic rifles $(7.62 \times 39 \mathrm{~mm}) 1,165,000$ cartridges $(7.62 \times 39 \mathrm{~mm}, \mathrm{M} 67)$ & 40 \\
\hline 5 July 2002 & $\begin{array}{l}120,000 \text { rounds of ammunition ( } 7.62 \mathrm{~mm} \text { for M84) } 11,250 \text { rounds of ammunition } \\
\text { (9MM NATO) } 75,000 \text { rounds of ammunition ( } 7.65 \mathrm{MM} \text { ) } \\
100 \text { missile launchers (RB M57) } \\
4500 \text { MINES FOR RB M57 } \\
60 \text { Automatic pistols (M84, } 7.65 \mathrm{~mm}) \\
20 \mathrm{M} \text { Pistols (CZ99, } 9 \mathrm{~mm} \text { ) } \\
10 \text { Black Arrow long-range rifles (M93, } 2.7 \mathrm{~mm}) \\
5 \text { Machine guns (M84, } 7.62 \mathrm{~mm}\end{array}$ & 33 \\
\hline 23 August 2002 & $\begin{array}{l}1000 \text { missile launches (RB M57) } \\
1,000 \text { mines for RB M57 } \\
50 \text { machine guns (M84, } 7.62 \mathrm{~mm}) \\
1,500 \text { automatic rifles }(7.62 \times 39 \mathrm{~mm}) \\
17 \text { Pistols (CZ99, } 9 \mathrm{~m}) \\
92,500 \text { rounds of ammunition }(7.62 \times 54 \mathrm{~mm}) \\
526,680 \text { rounds of ammunition }(7.62 \times 39 \mathrm{~mm}) \\
9,000 \text { rounds of ammunition }(9 \mathrm{~mm}) \\
6,000 \text { rounds of ammunition }(7.65 \mathrm{~mm}) \\
9 \text { hunting rifles }\end{array}$ & 38 \\
\hline 25 August 2002 & $\begin{array}{l}\text { 152, missile launchers } \\
1,000 \text { mines for RB M57 } \\
10 \text { automatic pistols (M84, } 7.65 \mathrm{~mm}) \\
5,200 \text { rounds of ammunition for the Black Arrow long -range rifle (M93, } 12.7 \mathrm{~mm}) \\
183,600 \text { rounds of ammunition }(7.62 \times 54 \mathrm{~mm}) \\
999,180 \text { rounds of ammunition }(7.62 \mathrm{cx} 39 \mathrm{~mm}) \\
2 \text { sets of rubber pipelines } \\
3 \text { propellers } \\
1 \text { rotor head } \\
17 \text { pistol holders }\end{array}$ & 38.5 \\
\hline
\end{tabular}


The outcome of the Personal communication revealed that "Arms were procured during the conflict in Liberia through counter trading (trade by barter) in timber, rubber and diamond with countries such as Libya, Burkina Faso, Cote d'Ivoire, and Guinea" (personal communication, June 2015). In similar vein, "the merchants and agents in Libya, Burkina Faso, Cote d'Ivoire and Guinea used highly secretive arms dealers to arms (supply/ transfer arms to) various warring factions in Liberia" (personal communication, June 2015). The defense contractors/arms vendors used in this transaction were given as indicated below (see box 2).

\section{Box 2: Arms Contractor/Vendors in the Context of the Liberia Conflict}

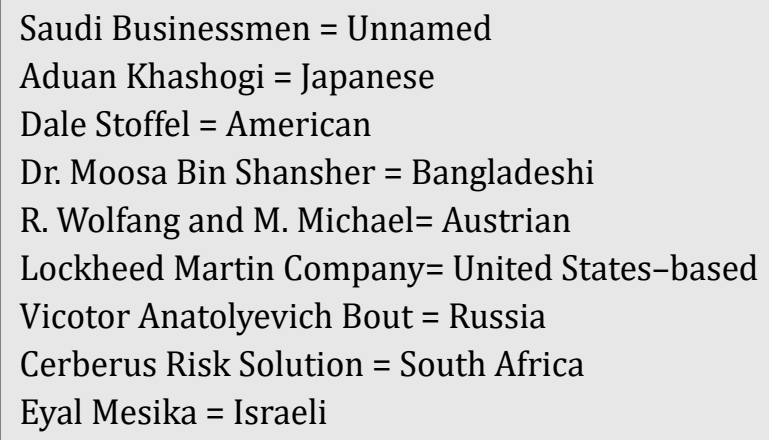

Source: personal communication; Abuja, June 2015.

\section{Dynamics of Arms Transfers and Proliferations during the Liberian Civil War}

At the outset of the Liberian Civil War, NPFL forces elicited arms and training from Libya and Burkina Faso in exchange for removing Doe's US-client regime from power. Libya was reportedly 'the NPFL's principal arms supplier', while Burkina Faso and Côte d'Ivoire served as transit points for arms as well as offering advisors and fighters. According to one report, three shipments of Kalashnikov rifles, RPG launchers and ammunition were transported from Bulgaria to Côte d'Ivoire by air in November 1989. The arms and ammunition were allegedly purchased by Libya through a German arms dealer and Swiss fiduciary company. This support helped make the NPFL the best-equipped rebel faction during the first Liberian civil war (Holtom, 2007).

Within the sub-Saharan Africa, the government of Burkina Faso, Côte d'Ivoire and Libya were motivated by a mixture of political and personal reasons for removing Doe from power, but they also benefited financially from supplying Taylor's forces with arms and ammunition. Although wealthy Americo-Liberian émigrés helped to fund military campaigns, revenues received from the illegal sales of, and extraction rights for, Liberian diamond, gold, iron ore, rubber and timber resources enabled Taylor to pay his supporters and arms dealers. In this regard, Taylor simply replaced Doe in the chain-linking 
international resource and extraction companies, arms dealers and Liberia. For example, it was known that Ivorian and French extraction companies established commercial ties with Taylor in the early 1990s, while former British soldiers were apparently involved in arranging 'arms-for-logs swaps' on Taylor's behalf (Holtom, 2007; Edeko, 2011).

Anecdotal and media reports have held that the USA assisted 'Prince' Yeduo Johnson's INPFL with arms, intelligence and transportation, but these have been denied by US officials. However, a strategic decision was made by the Nigerian leadership of ECOMOG to supply the INPFL with arms and ammunition. Guinea also allegedly used its ECOMOG contingent to funnel arms and ammunition to the ULIMO and LDF anti-Taylor rebel factions. Individual ECOMOG unit commanders and troops were also accused of selling weapons to different factions. Rebel factions also seized ECOMOG heavy weapons and military equipment following the capture of ECOMOG peacekeepers, and in one case the INPFL ransomed a platoon of Nigerians for two 105-mm howitzers (Fawole, 2001; Holtom, 2007).

Information regarding the scale of the arms transfers that circumvented the various arms embargoes imposed on Liberia since 1992 remains limited. Some data on the origins of the arms and ammunition held by Taylor's forces and rebel factions can be discerned from the findings of the disarmament programs that took place in Liberia between 22 November 1996 and 29 January 1997 and from December 2003-March 2005. The collection process is undertaken in 1996-97 only recovered a fraction of the arms and ammunition transferred to Liberia's warring factions during the period between 1989 and 1996. The weapons surrendered were on the whole small arms and light weapons (SALWS), with more than half of the assault rifles collected western-rifles and only a quarter being Kalashnikov rifles. Arms and ammunition from China, Czechoslovakia and the UK were also collected. UNMIL's DDR program had collected 28 314 weapons, 33604 pieces of heavy munitions and 6486136 rounds of small arms ammunition by March 2005. More than three-quarters of all weapons recovered were rifles, with Kalashnikov rifles representing the overwhelming majority of the arms collected during this collection process. UNMIL reportedly attempted to trace the origins of some weapons and also to calculate the return rate of weapons supplied from Iran and Yugoslavia in the period 2002-2003. UNMIL estimated that around half of Taylor's arsenal had been collected, in comparison with 38 percent of LURD's arsenal (Florquin \& Berman, 2005; Holtom, 2007).

Quantity of weapons collected during the Liberian Disarmament, Demobilisation and Reintegration (DDR) contrasted to estimates by UN officials that there were three weapons for every former combatant. The leaders of LURD, MODEL and Taylor's forces promised that all of their weapons would be surrendered to UNMIL. However, it has been alleged that on the eve of the disarmament period most of LURD's and MODEL's mortars and heavy weapons had been returned to Guinea and Côte d'Ivoire respective- 
ly. Reports also emerged stating that weapons were being smuggled into neighboring states in exchange for consumer goods. As far as can be discerned from the available data, patterns of arms transfers to rebel factions continued during the first years of the arms embargo in much the same way that they had before. Individuals, companies and supporters of Liberia's warring factions continued to source arms from Europe, in particular former Warsaw Pact and Soviet arsenals, to be exchanged for the natural resources extracted from territory held by Liberian warlords. For example, ULIMO-J used revenues from Bomi county's diamond mines to supply its forces, while the LPC relied upon exports of rubber. Neither of these factions could match the revenue streams of Taylor's NPFL, which were estimated to be worth $\$ 75$ million per year. There was one important change with regard to NPFL support following the introduction of the arms embargo. Ivorian support at the highest levels appeared to be waning by mid-1993, as President Félix Houphouët-Boigny and his successor Konan Bédié became more preoccupied with domestic problems. However, conflict goods and arms continued to cross the Liberian-Ivorian border (Weiss, 2005; Holtom, 2007).

The report of the first Panel of Experts on Liberia discussed a number of transfers to Taylor's regime in contravention of Resolution 788 (1992). The report indicated that there were 'persistent reports of ships to Harper, Greenville, Buchanan and Monrovia unloading weapons' and numerous eyewitness accounts of trucks bringing weapons from San Pedro and Abidjan (Côte d'Ivoire), originating from Burkina Faso. However, because the Panel was unable to find 'irrefutable evidence' the report focused solely upon shipments delivered by air for which documentation was available. Thus, the Panel documented a number of cases in which the Guinean-registered arms brokering firm Pecos, Victor Bout's air transport companies, owners of Liberian logging companies, Leonid Minin and Gus van 69 Kouwenhoven, and forged End-Use Certifications (EUCs) were all involved in the transfer of arms and ammunition to Taylor in contravention of the arms embargo (Edeko, 2011).

In the course of the Liberian armed conflict, the foremost allegation of arms violation submitted to the sanctions committee related to 68 tons of military equipment, which had been purchased from Ukraine's state's export company, Ukretsexport, using a EUC for Burkina Faso's National Defence Department. Major-General Felix Mujakperuo, ECOMOG's commander in Sierra Leone, accused Burkina Faso's President Compaoré of complicity in the diversion of the shipment to Liberia, and its subsequent transfer to the RUF in Sierra Leone, in spring 1999. Suspicions were aroused due to the fact that the Burkinabé armed forces used NATO-standard weaponry and not the former Soviet equipment delivered from Ukraine. This shipment was reportedly the first of several destined for Taylor's forces in Liberia and the RUF in Sierra Leone, which were arranged by Leonid Minin. Minin was the co-owner of Exotic Tropical Timber Enterprise (ETTE) - a logging company operating out of Liberia, which received preferential extraction rights in exchange for assisting with arms procurement for Taylor. When he 
was arrested in Monza, Italy on 5 August 2000, Minin was in the process of overseeing a considerable delivery of small arms and ammunition, which had been ordered from the Ukrainian state-owned company Spetstehnoexport using a photocopy of a EUC signed by Côte d'Ivoire's President General Robert Gueï. On 18 December 2002, Monza court judges ruled that they could not prosecute Minin for these deals due to the fact that they lacked jurisdiction to prosecute in arms trafficking cases in which the arms did not pass through Italian territory. The prosecution appealed, but on 9 January 2004 the Corte di Cassazione declared that it was unable to prosecute (Weiss, 2005; Edeko, 2005; Holtom, 2007).

Minin facilitated the meeting between the Panel of Experts and a number of associates also involved in supplying Taylor with arms and military equipment during the arms embargo. A Finnish national, Erkki Tammivuori, apparently helped with the delivery of Konkurs, Strela and Igla launchers and missiles in May 2000. These items had apparently not been used, as training had not been provided. The Panel also received a document, which had been in Minin's possession, indicating that a payment of US\$500,000 had been made to one of Victor Bout's transport companies by Singapore-registered Borneo Jaya Pte. Ltd - the mother company of the Liberian-based Oriental Timber Company (OTC) (Fawole, 2001; Florquin \& Berman, 2005; Holtom, 2007).

Taylor's regime had allegedly been striving to obtain Mi-8/Mi-17 transport helicopters and Mi-24/Mi-35 combat helicopters from former Soviet and Warsaw Pact inventories. The Panel of Experts saw two Mi-8/Mi-17s during their visits to Liberia in 2001, but their origins were not revealed. It was revealed that Pecos had used Guinean EUCs to acquire two Mi-24s from Kyrgyzstan in May 2000, which were bound for Taylor's forces. One of these Mi-24s was detained in Slovakia in February 2001, where it had been sent for repairs. The other Mi-24 left Slovakia in August 2000, following minor repairs. Although Liberian officials stated that they did not possess any combat helicopters, Guinean officials claimed to have shot down a Liberian helicopter gunship in 2000. The Guinean claims remain uncorroborated. Pecos also attempted to arrange for the transfer of two Mi-8s from Moldova to Liberia without a EUC, before Moldovan security services prevented the Mi-8s from leaving Moldova in March 2001 (Holtom, 2007).

Following the escalation of the Liberian crisis, LURD was formed in Freetown, Sierra Leone in July 1999. It claimed to rely upon weapons and ammunition captured from Liberian government forces. While independent experts have confirmed that LURD's armory contained weapons captured from Taylor's forces, it has been argued that Guinea used refugees, trucks and United Nations Mission in Sierra Leone (UNAMSIL) peacekeepers to supply arms to LURD forces. Evidence of this relationship appeared in 2002, when Taylor's forces captured 81-mm mortar rounds that bore markings from the United Arab Emirates (UAE). The UAE had reportedly sent 81-mm mortar rounds as part of an aid package to Guinean in December 1998. The Guinean Ministry of Defence 
(MOD) claimed that these mortar rounds had been lost in an arms depot fire in 2001 (Holtom, 2007; Edeko, 2011).

Elsewhere within the conflict sub-region, the Guinean company Katex Mines has also been accused of supplying arms to LURD. The Panel of Experts suspected Katex of arranging flights carrying Iranian produced arms and ammunition for LURD from Lviv (Ukraine) to Conakry (Guinea) via Tehran between February 2002 and August 2003, a suggestion that others have supported. The Iranian origins of mortar rounds used during the summer 2003 LURD offensive were confirmed by a number of experts, although these rounds could potentially have been taken from Taylor's forces, which are also thought to have received arms and ammunition from Iran With the election victory of Laurent Gbagbo in Côte d'Ivoire, one of Taylor's former sponsors allegedly began supplying the anti-Taylor movement MODEL 'with uniforms, weapons and money', including Ukrainian-produced arms with US assistance (Edeko, 2011; Holtom, 2007).

In 2002, the report of the Panel of Experts' detailed six arms deliveries of surplus stocks from the Yugoslavia National Army to Liberia, via Libya, in the summer of 2002. Yugoslav authorities claimed to have received an export license from the Nigerian MOD for thousands of SALWs units, grenades and millions of cartridges and assorted ammunition, which were diverted to Taylor's forces. Libya was also reportedly involved in arranging for delivery of arms and ammunition from Iran via Benin, Libya and Sudan in the summer of 2003. The exact cargo of only one of these flights is known, as the flight that arrived in Monrovia from Tehran on 7 August, 2003 was seized by Nigerian peacekeepers. Preliminary investigations into the origin of the weapons seized revealed that the rifles were 'very similar' to China's Norinco 7.62-mm Type 56-1 rifles. It has been alleged that Liberian timber enterprises, in particular Gus van Kouwenhoven's Oriental Timber Company (OTC), played a central role in facilitating regular arms transfers to Taylor's forces from China National Aero-Technology Import and Export Corporation (CATIC) between 2001 and 2003. A number of OTC arms deliveries for Taylor arrived at Buchanan and Harper ports from/via Bulgaria, China, France, Hong Kong, Libya and Nigeria. Kouwenhoven was arrested in Rotterdam on 18 March 2005 and charged with war crimes and breaking the UN arms embargo on Liberia in the period 2001-2003. In June 2005, a Dutch court in the Hague found Kouwenhoven guilty of violating the UN arms embargo, because his OTC illegally imported weapons into Liberia by sea for use by Taylor's forces and OTC militias. He was given an eight-year prison sentence, although not convicted on the war crimes count (Holtom, 2007; Edeko, 2011).

Rather curiously, a French arms dealer, notorious for being involved in transfers of arms from Bulgaria to Liberia between 1991 and 1998, allegedly re-activated his BulgariaLiberia arms pipeline in May 2002, supplying Kalashnikov rifles, RPG launchers and Glock pistols. With Burkina Faso and Libya again apparently involved in transferring 
arms to Taylor's forces, it appeared as if the transfer patterns of the early 1990s were being repeated in the period after 2000 . There were, however, significant changes in Taylor's suppliers and sponsors between these two periods. Chinese arms transfers reportedly increased dramatically at this time, and allegations were also made that Nigerian diplomats were involved in arranging for arms shipments to Liberia and Taylorbacked forces in Sierra Leone (Weiss, 2005).

The outcome of the investigation by the Panel of Experts revealed no evidence of weapons trafficking into Liberia since August 2003. However, organized, international smuggling networks remain place and could be reactivated at any time. The 2004 Panel of Experts' report also concurred with views expressed by NGOs that arms and ammunition continued to be smuggled across Liberia's borders into neighbouring states. In 2005, the UN sanctions committee on Liberia received two requests for consignments of arms to be delivered to the NTGL. On 8 August 2005, the US Mission to the UN reportedly requested an exemption to the arms embargo to ship arms and training equipment for the new Liberian military. An exemption was granted, although one item was not permitted. The second request was submitted on 2 September 2005 by the NTGL, requesting permission to import 300 side-arms for police officers being trained in Nigeria. The sanctions committee looked favorably upon the request but sought more information on the proposed supplier. By the end of 2005, the committee had not received a request from an exporting state. It later transpired that Nigeria was to supply the Liberian police force with 50 Beretta pistols, 6,000 smoke cartridges and 3,000 hand grenades. The Panel of Experts' 2006 report also revealed that Romania had supplied the AFL with 150 Kalashnikov rifles fitted with bayonets and 69,000 rounds of $7.62 \times 39-\mathrm{mm}$ ammunition (Holtom, 2007; Edeko, 2011).

\section{Collateral Implications of SALWs Proliferation for Liberia's National Security}

It was generally acknowledged by the research respondents that the impacts and complications of SALWs proliferation in Liberia have held far-reaching implications for the country's national security. For convenience of effective presentation, the various views shared by the research respondents in relation to the implications of SALWs proliferation in Liberia are synchronized and presented under the following sub-themes:

Escalation of tension and hostilities: The free flow of small arms and light weapons in Liberia led to the escalation of civil tension and hostilities in the country. The constant supply and circulation of arms/weapons in Liberia in the1990s provided impetus for the massive armed violence that characterized and complicated the Liberian crisis. The consequence of this development was evident in the huge humanitarian costs of the crisis, failure of peace talks and peace deals, and the general escalation of civil tension and hostilities throughout the country (personal communication, June 2015).

The proliferation of Rebels/militia groups: SALWs proliferation in the context of the Liberian crisis inspired the emergence of a multiplicity of armed groups, organized 
militias and rebel movements. Prominent among these groups are the Liberians United for Reconciliation and Democracy (LURD), composed of groups that lost the 1989-96 civil war and the Movement for Democracy in Liberia (MODEL), which was formed in 2003 as a splinter arm of the LURD, largely representing the interest of the ethnic Krahn (Small Arms Survey, 2005). In addition to the aforementioned there were a number of militia and paramilitary groups, some of which were pro-government in orientation. These armed groups were all engaged in a fierce arm struggle that compounded and prolonged the Liberian crisis (personal communication, June 2015).

Internationalization of the Liberian crisis: SALWs proliferation, among other things, led to transnational degeneration of the Liberian crisis. At some points, the crisis led to contagious or spillover incidents in neighboring Guinea, Sierra Leone and Cote d'Ivoire. These countries incidentally became proxied to the Liberian crisis, serving as sources of arms/weapons as well as bases for rebels training and recruitments. In effect, the Liberian crisis occasioned a spate of SALWs proliferation that created sapping security volatility and emergency in the whole of the Mano River Region (cf. Alemika, 2014). The free flow of small arms and light weapons in this zone during and after the Liberian crisis led to the intractability of civil strife and armed conflicts in that context in the late 1990s and 2000s (personal communication, June 2015).

Humanitarian consequences: SALWs proliferation in the context of the Liberian crisis led to dire humanitarian situation in Liberian and its neighborhood. This was exemplified in the high incidence of human fatality and morbidity that was associated with the crisis. Apart from staggering tolls of human death and injury, the crisis also resulted in gross population displacement, leading to crises of internally displaced persons (IDPs) and refugees. Besides, there were cases of rape, torture, armed victimization, and destruction of livelihood. This trend had immense critical implication for human security in Liberia and the adjoining region (personal communication, June 2015).

Incidence of armed violence and criminality: The level of SALWs proliferation that characterized the Liberian crisis was responsible for the spate of rural and urban armed violence and criminality in the country in the late 1990s and 2000s. In the aftermath of the national crisis, Liberian is still grappling with the challenge of public security in the face of high incidence and prevalence of violent crime perpetrated by the means of small arms. Organized criminal gangs in the country have free access to huge stockpiles of arms and ammunition transferred into the country during the civil conflict. This enables them to operate with brutal efficiency, with far-reaching implications for public safety in the country. Prominent patterns of arms criminality in Liberia include banditry, kidnapping, cultism and gang violence (Personal communication, June 2015).

Internal security challenge: SALWs proliferation has posed a huge internal security challenge to the government of Liberia. This is evident in terms of high public spending on public security, disarmament programme, demobilization of armed groups, and crime 
control. This translates to huge real and opportunity costs in relation to the country's fiscal priorities (personal communication, June 2015).

Allied complications of SALWs proliferation: Other complications of SALWs proliferation in Liberia within the period under review included child and girl soldering, warlordism, homicides, and sundry organized crime. For instance, the phenomenon of child/girl soldering promoted the culture of arm violence and restiveness among the Liberian youth. The ripples of this development are evident in the spate of cultism and gang violence among the youth population in the urban and suburban enclaves of Liberia (personal communication, June 2015).

\section{Conclusion}

The problem of SALWs proliferation is a national security challenge in both conflict-ridden and conflict-free countries. In conflict-ridden countries, however, the issue becomes more problematic and more glaring. This is in view of the fact that conflict and SALWs proliferation are intricately interrelated. In other words, armed conflicts tend to drive the need for the proliferation of arms/weapons. Conversely, proliferation of arms/ weapons tends to provide impetus for the escalation of armed conflict. In this wise, the two phenomena could be said to be mutually related and reinforcing.

As we have seen in the case of Liberia, SALWs proliferation was one of the factors that complicated and escalated the Liberian crisis. The outcome of our analysis shows that the complications of SALWs proliferation in Liberia during and after the National crisis (1989-2003) posed a threat to the country's national security. The threat is evident in the collateral impact of armed violence that characterized the Liberian Crisis as well as the wave of armed criminality that has punctuated the country's history in the aftermath of the crisis. In the light of its destructive impacts and complications vis-à-vis sustainable peace, security and stability, this study submits that SALWs proliferation has posed a threat to Liberian national security in both the conflict and post-conflict eras.

\section{References}

1. Adebajo, A. (2002). Liberia's civil war: Nigeria, ECOMOG and Regional Security in West Africa. London: Lynne Rienner.

2. Alemika, E. E. O. (2014). The Impact of Organized Crime on Governance in West Africa. Abuja: Friedrich Ebert Stiftung.

3. Edeko, S. E. (2011). The Security Implications of Civil Wars in Africa: Liberia and Darfur in Perspective. Sacha Journal of Human Rights, 1(1), 50-67.

4. Fawole, W. A. (2001). Military power and Third Party Conflict Mediation in West Africa: The Liberian and Sierra Leone Case Studies. Ile-ife: Obafemi Awolowo University Press.

5. Gyong, J. E., \& Ogbadoyi, C. (2013). Public Perception of the Proliferation of Illegal and Small Arms and Ethno-Religious Conflicts in Kaduna Metropolis, Kaduna State, Nigeria. American International Journal of Contemporary Research 3(1), 38-51. 
6. Florquin, N., \& Berman, E. G. (eds). (2005), Armed and Aimless: Armed Groups, Guns, and Human Security in the ECOWAS Regions. Geneva: Small Arms Survey Publication.

7. Gariba, E. B. (2011). Post-conflict Development in Liberia: Governance, Security, Capacity-Building and a Developmental Approach. African Journal of Conflict Resolution, 11(2), 106-132.

8. Holtom, P. (2007). United Nations arms embargoes; their Impacts on Arms Flow and Target Behavior-Case Study, Liberia, 1992-2006. Stockholm: International Peace Research Institute.

9. Onuoha G. (2006). Contextualizing the Proliferation of Small Arms and Light Weapons in Africa. London: Oxford University Press.

10. Sawyer, A. (2004). Violent Conflicts and Governance Challenges in West Africa: The Case of the Mano River. Journal of Modern African Studies, 43(3), 437-463.

11. Small Arms Survey (2005). Armed and Armless: The Armed Groups, Guns, and Human Security in the ECOWAS Region. Geneva: A Small Armed Survey Publication Commissioned by Human Security Network.

12. Stohl, R., \& Hogendoorn, E. J. (2010). Stopping the destructive Spread of Small Arms: How Small Arms and Light Weapons Proliferation undermines Security and Development. Washington: Center for American Progress.

13. UNGA. (2009). UNGA (2009). Report of the Secretary-General on 'Promoting Development through the Reduction and Prevention of Armed Violence', (A/64/228). Geneva: United Nations General Assembly.

14. Weiss, T. (2005). Perpetrating power: Small arms and post-conflict Sierra Leone and Liberia. Pretoria: Institute for Security Studies.

15. Wezema, P. O., \& Wezeman, S. T. (2011). Arms Flows to Sub-Sahara Africa. SIPRI Policy Paper No. 30. Solna: SIPRI. 